\title{
MORPHOMETRIC STUDY OF THE POSTMORTEM HUMAN SPLEEN
}

\author{
RAYHAN KA ${ }^{1}$, ARA S $^{2}$, NURUNNABI ASM ${ }^{3}$, KISHWARA S $^{4}$, NOOR M ${ }^{5}$
}

\begin{abstract}
:
Context: The spleen is the largest lymphoid organ in the human body. The morphology of spleen is affected by number of disorders, e.g. abnormalities of the cells, which populate within the spleen or disturbance of its storage function. Therefore, the size of the spleen can be regarded as an indicator of the disease process.
\end{abstract}

Study design: Cross-sectional, descriptive type of study.

Place and period of study: Department of Anatomy, Dhaka Medical College, Dhaka, from August 2005 to June 2006.

Materials: The present study was performed on 70 postmortem human spleens collected from unclaimed dead bodies which were under autopsy examination in the Department of Forensic Medicine of Dhaka Medical College, Dhaka.

Methods: The samples were divided into six different age groups i.e. group A ( $0-19$ years), $B$ (20-29 years), C (30-39 years), D (40-49 years), $E$ (50-59 years) and $F$ ( $\geq 60$ years). The length, breadth and thickness of the spleen were measured. The number of the notch in its upper and lower poles was observed. The presence of any accessory spleen was also observed in situ.

Results: The length, breadth and thickness of the spleen were found to have no significant changes with advancing age. Notches were present on the upper border of spleen in $88.57 \%$ of samples and lower border of the spleen in $27.14 \%$ of samples. Accessory spleen was found in $24.28 \%$ of cases.

Key words: Human spleen, length, breadth, thickness, splenic notch, accessory spleen.

J Dhaka Med Coll. 2011; 20(1) : 32-36.

\section{Introduction:}

The spleen is a largest single mass of lymphoid tissue in the human body ${ }^{1}$, which is closely associated with the circulating system. The spleen is the most vascular organ in the human body $^{2}$, which is involved in the regulation of circulating blood volume ${ }^{3}$. Approximately 350 L of blood passes through it per day ${ }^{4}$. The spleen receives approximately $5 \%$ of the cardiac output $^{5}$, and $40 \%$ source of the blood in the portal circulation ${ }^{6}$. The spleen contains about one unit of blood at a given time ${ }^{2}, 25 \%$ of total lymphocytes in the body, 30 to $40 \mathrm{ml}$ of mature RBC and one-fourth of the circulating platelets $^{7}$. The size of the spleen is used as an indicator of disease activity in a variety of reticuloendothelial system. Measurement of the splenic length in the routine clinical practice is a very good indicator of actual splenic size $^{8}$. Splenomegaly is an important diagnostic clue to the existence of an underlying disorder ${ }^{9}$. The spleen is affected by number of disorders e.g. abnormalities of the cells that populate within the spleen like malaria, kalaazar etc. ${ }^{5}$, or disturbance of storage function of the spleen like sarcoidosis, leukaemia etc. ${ }^{10}$, However, in those cases, removal of the spleen is the choice of treatment to recover. If any accessory spleen is present, must be removed during operation; otherwise the disease may

1. Dr. Khandaker Abu Rayhan, Associate Professor, Department of Anatomy, Popular Medical College, Dhaka.

2. Prof. Shamim Ara, Professor and Head, Department of Anatomy, Dhaka Medical College, Dhaka.

3. Dr. Abu Sadat Mohammad Nurunnabi, Lecturer, Department of Anatomy, Dhaka Medical College, Dhaka.

4. Dr. Segupta Kishwara, Assistant Professor, Department of Anatomy, Dhaka Medical College, Dhaka.

5. Dr. Masumatun Noor, Medical Officer, Department of Paediatrics, Community Based Medical College \& Hospital, Mymensingh.

Correspondence: Dr. Khandaker Abu Rayhan, Associate Professor, Department of Anatomy, Popular Medical College, Dhanmondi, Dhaka, Cell Phone: +8801912178652, Email: rayhanripon_10@yahoo.com 
recur ${ }^{5}$. Therefore, detail morphological knowledge is essential for diagnosis and management of splenic diseases. The present study was designed to see the age related variation in length, breadth, thickness of the spleen and number of notches on the upper and lower borders of the spleen. Presence of accessory spleen was also observed.

\section{Materials and Methods:}

The present study was performed on 70 human spleens of both sexes in different age groups. The collected samples were divided into six different age groups for convenience of the study (Table-I). The study was done in the Department of Anatomy, Dhaka Medical College, Dhaka, from August 2005 to June 2006. The samples of human spleen were collected from unclaimed dead bodies, after all legal procedure that was under examination in the Department of Forensic Medicine of Dhaka Medical College, Dhaka. The samples were collected from the dead bodies within 2436 hours of death which were without any signs of decomposition, crushing or cutting injury, gross abnormality in size and history of poisoning. The samples were tagged immediately, which was bearing a code number for subsequent identification. Just after removal of spleen from abdominal cavity, the samples were gently washed with normal saline at $37^{\circ} \mathrm{C}$ temperature, then dried with the help of blotting paper and fixed in 10\% formol saline solution.

\section{Measurement procedures:}

The length and breadth of the spleen were measured with the help of a measuring tape graduated in $\mathrm{cm}$ (according to Lamb et al. ${ }^{8}$ ), where maximum length was measured between the splenic tips along the diaphragmatic surface of the spleen, and maximum breadth was determined between the upper and lower border of the spleen at a plane perpendicular to the length. The thickness of the spleen was taken with the help of a slide calipers at maximum anteriorposterior dimension of the spleen ${ }^{8}$. The total number of notches of the upper and lower borders of the spleen was observed. After separation of the spleen and the splenic artery from the surrounding structures, it was observed meticulously, whether any accessory spleen was present.

Ethical clearance: The present study was approved by the Ethical Review Committee of Dhaka Medical College, Dhaka.

\section{Results:}

Length of the spleen

In the present study, the mean length of the spleen were $9.49 \pm 1.41 \mathrm{~cm}$ in age group A (0-19 years), $9.56 \pm 1.16 \mathrm{~cm}$ in age group $B(20-29$ years), $10.41 \pm 1.35 \mathrm{~cm}$ in age group $\mathrm{C}$ (30-39 years), $10.95 \pm 1.58 \mathrm{~cm}$ in age group $\mathrm{D}(40-49$ years), $9.73 \pm 1.16 \mathrm{~cm}$ in age group $\mathrm{E}(50-59$ years) and $8.86 \pm 0.96 \mathrm{~cm}$ in age group $\mathrm{F}$ (e"60 years). The length of the spleen shows significant difference between $\mathrm{A}$ and $\mathrm{D}$ group $(\mathrm{P}<0.05), \mathrm{B}$ and $\mathrm{C}$ group $(\mathrm{P}<0.05), \mathrm{B}$ and $\mathrm{D}$ group $(P<0.01), C$ and $F$ group $(P<0.05), D$ and $F$ group $(\mathrm{P}<0.01)$. The other difference did not reach up to the level of significance.

Table-I

Age distribution in different group

\begin{tabular}{lcc}
\hline Group & Age limit & No. of samples \\
\hline A & 0 - 19 years & 9 \\
B & $20-29$ years & 20 \\
C & $30-39$ years & 18 \\
D & $40-49$ years & 11 \\
E & $50-59$ years & 7 \\
F & $\geq 60$ years & 5 \\
\hline
\end{tabular}

Breadth of the spleen

In the present study, the mean breadth of the spleen were $5.62 \pm 0.93 \mathrm{~cm}, 4.99 \pm 1.57 \mathrm{~cm}$, $5.02 \pm 1.49 \mathrm{~cm}, 6.49 \pm 1.88 \mathrm{~cm}, 5.53 \pm 1.73 \mathrm{~cm}$ and $5.16 \pm 0.99 \mathrm{~cm}$ in age group A, B, C, D, E and F respectively. The breadth of the spleen shows significant difference between $\mathrm{A}$ and $\mathrm{D}$ group $(\mathrm{P}<0.05)$, $\mathrm{B}$ and $\mathrm{C}$ group $(\mathrm{P}<0.05), \mathrm{B}$ and $\mathrm{D}$ group $(P<0.01), C$ and $F$ group $(P<0.05), D$ and $F$ group $(\mathrm{P}<0.01)$. The other difference did not reach up to the level of significance.

Thickness of the spleen

The mean thickness of the spleen were $1.97 \pm 0.53 \mathrm{~cm}, 1.80 \pm 0.54 \mathrm{~cm}, 2.08 \pm 0.64 \mathrm{~cm}$, 
$2.16 \pm 1.12 \mathrm{~cm}, 2.32 \pm 1.32 \mathrm{~cm}$ and $1.80 \pm 0.59 \mathrm{~cm}$ in age group A, B, C, D, E and F respectively. The thickness of the spleen shows significant difference between $A$ and $D$ group $(P<0.05), B$ and $C$ group $(P<0.05), B$ and $D$ group $(P<0.01), C$ and $F$ group $(P<0.05), D$ and $F$ group $(P<0.01)$. The other difference did not reach up to the level of significance.

\section{Table-IIa}

Length, breadth and thickness of the spleen in different study group

\begin{tabular}{lcccc}
\hline Group (n) & $\begin{array}{c}\text { Length }(\mathrm{cm}) \\
\text { Mean } \pm \text { SD }\end{array}$ & \multicolumn{2}{c}{ Breadth (cm) Thickness (cm) } \\
& & Mean & Mean \pm SD \\
\hline A & (9) & $9.49 \pm 1.41$ & $5.62 \pm 0.93$ & $1.97 \pm 0.53$ \\
& & $(7.10-11.20)$ & $(4.10-6.80)$ & $(1.10-2.90)$ \\
B & $(20)$ & $9.56 \pm 1.16$ & $4.99 \pm 1.57$ & $1.80 \pm 0.54$ \\
& & $(7.20-11.20)$ & $(2.90-8.20)$ & $(1.20-3.30)$ \\
C & $(18)$ & $10.41 \pm 1.35$ & $5.02 \pm 1.49$ & $2.08 \pm 0.64$ \\
& & $(7.40-13.00)$ & $(3.30-7.80)$ & $(0.80-3.20)$ \\
D & $(11)$ & $10.95 \pm 1.58$ & $6.49 \pm 1.88$ & $2.16 \pm 1.12$ \\
& & $(7.40-13.00)$ & $(3.20-8.20)$ & $(1.20-4.80)$ \\
E & $(7)$ & $9.73 \pm 1.16$ & $5.53 \pm 1.73$ & $2.23 \pm 1.32$ \\
& & $(8.30-11.40)$ & $(3.30-7.80)$ & $(1.20-5.10)$ \\
F & $(5)$ & $8.86 \pm 0.96$ & $5.16 \pm 0.99$ & $1.80 \pm 0.59$ \\
& & $(7.40-9.70)$ & $(3.50-6.00)$ & $(1.10-2.50)$ \\
\hline
\end{tabular}

Figures in parentheses indicate range. Statistical analyses done by ANOVA (multiple comparison).
Table-IIb

Relationship between age and length, breadth and thickness of spleen

\begin{tabular}{lll}
\hline Parameters & r value & P value \\
\hline Length of spleen & +0.050 & $>0.50 \mathrm{~ns}$ \\
Breadth of spleen & +0.082 & $>0.50 \mathrm{~ns}$ \\
Thickness of spleen & +0.054 & $>0.50 \mathrm{~ns}$ \\
\hline
\end{tabular}

Statistical analysis done by Pearson correlation coefficient $(\mathrm{r})$ test, $\mathrm{ns}=$ not significant, $* * *=$ significant.

Number of notches at the upper and lower borders of the spleen

In the present study, the notch absent in 8 samples, one notch present in each of 35 samples, two notches were present in each of 17 samples and three notches were present in 10 samples at the upper border of the spleen. Notch were absent in 51 samples, one notch present in 18 samples and two notches were present in 1 sample at the lower border of the spleen.

\section{Accessory spleen}

Accessory spleen was present in 3 samples (33.3\%), 4 samples $(20.0 \%), 5$ samples $(27.8 \%)$, 3 samples $(27.3 \%), 1$ sample $(14.30 \%)$ and 1 sample $(20 \%)$ in age group A, B, C, D, E and F respectively.

Table-III

Number of notches at the upper and lower border of spleen in different study group

\begin{tabular}{|c|c|c|c|c|c|c|c|c|c|}
\hline \multirow[t]{3}{*}{ Group (n) } & \multicolumn{8}{|c|}{ Number of notches at the upper border } & \multirow{3}{*}{$P$ value } \\
\hline & \multicolumn{2}{|c|}{0} & \multicolumn{2}{|c|}{1} & \multicolumn{2}{|c|}{2} & \multicolumn{2}{|c|}{3} & \\
\hline & No. & $\%$ & No. & $\%$ & No. & $\%$ & No. & $\%$ & \\
\hline A (9) & 2 & $(22.2)$ & 5 & $(55.8)$ & 0 & - & 2 & $(22.2)$ & $\mathrm{P}>0.10^{\mathrm{ns}}$ \\
\hline B (20) & 2 & $(10.0)$ & 12 & $(60.0)$ & 4 & $(20.0)$ & 2 & $(10.0)$ & \\
\hline C (18) & 1 & $(5.6)$ & 10 & $(56.0)$ & 5 & $(28.0)$ & 2 & (11.2) & \\
\hline $\mathrm{D} \quad(11)$ & 2 & $(18.2)$ & 2 & (18.2) & 5 & $(45.5)$ & 2 & (18.2) & \\
\hline $\mathrm{E} \quad(7)$ & 0 & - & 5 & $(71.4)$ & 2 & (28.6) & 0 & - & \\
\hline F (5) & 1 & (20.0) & 1 & (20.0) & 1 & (20.0) & 2 & $(40.0)$ & \\
\hline \multirow[t]{3}{*}{$\overline{\text { Group (n) }}$} & \multicolumn{8}{|c|}{ Number of notches at the lower border } & \\
\hline & \multicolumn{2}{|c|}{0} & \multicolumn{2}{|c|}{1} & \multicolumn{2}{|c|}{2} & \multicolumn{2}{|c|}{3} & $P$ value \\
\hline & No. & $\%$ & No. & $\%$ & No. & $\%$ & No. & $\%$ & \\
\hline 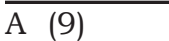 & 6 & $(66.7)$ & 3 & (33.3) & 0 & - & 0 & - & $\mathrm{P}>0.10^{\mathrm{ns}}$ \\
\hline B (20) & 19 & (95.0) & 0 & - & 1 & $(5.0)$ & 0 & - & \\
\hline C (18) & 11 & (61.1) & 7 & $(38.9)$ & 0 & - & 0 & - & \\
\hline D (11) & 8 & (72.7) & 3 & (27.3) & 0 & - & 0 & - & \\
\hline E $\quad(7)$ & 4 & $(57.1)$ & 3 & (42.9) & 0 & - & 0 & - & \\
\hline $\mathrm{F} \quad(5)$ & 3 & $(60.0)$ & 2 & $(40.0)$ & 0 & - & 0 & - & \\
\hline
\end{tabular}

Statistical analyses done by Chi square test, $\mathrm{ns}=$ not significant. 
Table-IV

Presence of accessory spleen in different study groups

\begin{tabular}{cccccccc}
\hline Group & $(\mathrm{n})$ & \multicolumn{2}{c}{ Present } & & \multicolumn{2}{c}{ Absent } & P value \\
\cline { 3 - 4 } & & No. & $(\%)$ & & No. & $(\%)$ & \\
\hline A & 9 & 3 & $(33.3)$ & & 6 & $(66.7)$ & \\
B & 20 & 4 & $(20.0)$ & & 16 & $(80.0)$ & $>0.50^{\text {ns }}$ \\
C & 18 & 5 & $(27.8)$ & & 13 & $(72.2)$ & \\
D & 11 & 3 & $(27.3)$ & & 8 & $(72.7)$ & \\
E & 7 & 1 & $(14.3)$ & & 6 & $(85.7)$ & \\
F & 5 & 1 & $(20.0)$ & & 4 & $(80.0)$ & \\
\hline
\end{tabular}

Statistical analysis done by Chi square test, $\mathrm{ns}=$ not significant

\section{Discussion:}

The length, breadth and thickness of the spleen described by the Ahmed ${ }^{11}$, were similar to the present study. The result of present study is also similar with Machálek et al. ${ }^{12}$ and Michels ${ }^{13}$. This finding described by Coetzee ${ }^{6}$, Machálek et al. ${ }^{14}$, Spielmann et al. ${ }^{15}$, Meire et al. ${ }^{16}$ was higher than the present study. The length, breadth and thickness of the spleen were found to decrease with advancing age.

There were 1 to 3 notches present on the upper border of the spleen in $88.57 \%$ of samples and 1 to 2 distinct notches present on the lower border of the spleen in $27.14 \%$ of samples. Number of notches on the spleen described by Voboril ${ }^{17}$ and Michels ${ }^{13}$ were similar to the present study. However, it was slightly lower than described by Machálek et al. ${ }^{12}$. Moore and Dally $^{18}$ and Machálek et al. ${ }^{14}$ found that accessory spleens were present in only 10\% normal population, which was lower than the present study (24.28\%). However, accessory spleen is not uncommon ${ }^{19}$.

\section{Conclusion:}

Further studies with larger sample in different age group including sexes, height, body weight, body surface area, basal metabolic index with enough period of time are recommended.

\section{References:}

1. Borley NR. Spleen. In: Standring S, Borley NR, Collins P, Crossman AR, Gatzoulis MA, Heally JC, et al. eds. Gray's Anatomy: The anatomical basis of clinical practice. $40^{\text {th }}$ ed. Edinburgh: Elsevier Churchill Livingstone; 2008. p. 1191-5.

2. Klepac SR, Samett EJ. Spleen, Trauma. Available from: http://emedicine.medscape.com/article/ 373694-overview. [Accessed on 20. 12. 2010].

3. Mebius RE, Kraal G. Structure and function of the spleen. Nat Rev Immunol 2005; 5(8): 606-16.

4. Garden OJ, The spleen. In: Williams NS, Bulstrode CJK. O'Connell PR. eds. Bailey and Love's short practice of surgery. $25^{\text {th }}$ ed. London:Hodder Arnold; 2008. p. 1101-10.

5. Beauchamp RD, Holzman MD. Fafiam TC, Spleen. In: Townsend CM, Beauchamp RD. Evers BM, Mattox KL. eds. Sabiston Text book of surgery: The biological basis of modern surgical practice. Vol. $217^{\text {th }}$ ed. Bangalore: Saunders Elsevier ; 1994. p. 1679-1708..

6. Coetzee T. Clinical anatomy and physiology of the spleen. S Afr Med J 1982; 61(20): 737-46.

7. Doan CA. The spleen: its structure and functions. Postgrad Med 1968; 43(5): 126-31.

8. Lamb PM, Lund A, Kanagasabay RR, Martin A, Webb JAW, Reznek RH. Spleen size: how well do linear ultrasound measurements correlate with three-dimensional $\mathrm{CT}$ volume assessments? $\mathrm{Br} \mathrm{J}$ Radiol 2002; 75(895): 573-7.

9. Kumar V, Abbas AK, Fausto N. Aster JC. eds. Robbins and Cotran pathologic basis of disease. $8^{\text {th }}$ ed. New Delhi: Saunders Elsevier; 2010. p. 632-5.

10. Maier RV. Spleen. In: Mulholland MW, Lillemoe KD, Doherty GM, Maier RV, Upchurch GR Jr. eds. Greenfield's surgery: scientific principles and practice. $4^{\text {th }}$ ed. Philadelphia: Lippincott Williams \& Wilkins; 2005. 
11. Ahmed AKMF. An anatomical study of human postmortem spleen in relation to age, sex and smoking in Bangladeshi people. [Thesis]. IPGMR; Dhaka University.

12. Machálek L, Houserková D, Holibková A. A contribution to the vascular anatomy of the human spleen. Acta Univ Palacki Olomuc Fac Med 1996; 140: 11-5.

13. Michels NA. The variational anatomy of the spleen and splenic artery. Am J Anat 1942; 70: 21-72.

14. Machálek L, Holibková A, Tüma J, Houserková D. The size of the splenic hilus, diameter of the splenic artery and its branches in the human spleen. Acta Univ Palacki Olomuc Fac Med 1998; 141: 45-8.
15. Spielmann AL, DeLong DM, Kliewer MA. Sonographic evaluation of spleen size in tall healthy athletes. AJR 2005; 184(1): 45-9.

16. Meire HB, Cosgrove DO, Dewbury K, Farrant P. Clinical ultrasound: a comprehensive text abdominal and general ultrasound. Vol. 1. $2^{\text {nd }}$ ed. London: Churchill Livingstone; 2001.

17. Voboril Z. Relationship of the notches and fissures on the surface of the human spleen to the splenic segments. Folia Morphol (Praha) 1983; 3(2): 163-7.

18. Moore KL, Dally AF. Clinically oriented anatomy. $5^{\text {th }}$ ed. Philadelphia: Lippincott Williams \& Wilkins; 2006. p. 218-6.

19. Moore KL, Persaud TVN. The developing human: clinically oriented embryology. $6^{\text {th }}$ ed. Philadelphia: W. B. Saunders; 1998. p. 283. 